University of Michigan Law School

University of Michigan Law School Scholarship Repository

1981

\title{
Alfred F. Conard and Allan F. Smith
}

Terrance Sandalow

University of Michigan Law School, sandalow@umich.edu

Follow this and additional works at: https://repository.law.umich.edu/other

Part of the Legal Biography Commons

\section{Recommended Citation}

Sandalow, Terrance. "Alfred F. Conard and Allan F. Smith." Mich. L. Rev. 79 (1981): 371-4.

This Tribute is brought to you for free and open access by the Faculty Scholarship at University of Michigan Law School Scholarship Repository. It has been accepted for inclusion in Other Publications by an authorized administrator of University of Michigan Law School Scholarship Repository. For more information, please contact mlaw.repository@umich.edu. 


\section{ALFRED F. CONARD and ALLAN F. SMITH}

\section{Terrance Sandalow*}

I am delighted to be able to participate in honoring Al Conard and Allan Smith, but I confess that I am puzzled as to why I have been invited to speak. I have not had either as a teacher. Moreover, their scholarly contributions are sufficiently removed from my areas of interest that I cannot evaluate the importance of their work. Nor was I in a good position to observe Allan's service as Dean or as Vice President for Academic Affairs.

I am, in short, qualified to testify only about the reputations of our two honored guests. Since that is so, it is appropriate to inquire when testimony concerning reputation is admissible. The answer to that inquiry is clear, but disquieting. Testimony concerning reputation is generally held to be admissible when character is at issue. I cannot help but wonder why the editors of the Law Review have concluded that the characters of Professors Conard and Smith are at issue.

Nevertheless, as is well known, the dean is the servant of the student body, and so I shall proceed to carry out my marching orders. I suspect, however, that my stated intention to testify concerning their reputations may be causing Professors Conard and Smith some anxiety. Since this dinner is in their honor, I want to move as quickly as possible to allay their fears. According to McCormick's Handbook of the Law of Evidence, the rule permitting evidence of reputation is a "merciful" one: it authorizes only evidence of "good character." Thus constrained, my testimony can be quite brief.

Al Conard came to the Law School in 1954, having previously served as a faculty member at the University of Kansas City and at the University of Illinois. All told, he has been a law teacher for thirty-seven years. There are law teachers who have understood James Garfield's nostalgic reminiscence of Mark Hopkins to mean that the education of students is best advanced by offering them the opportunity to share the teacher's thoughts about whatever currently engages his interest. Teaching which rests upon that premise may at times provide students an enriching and even an exhilarating experi-

- Dean and Professor of Law, University of Michigan. A.B. 1954, J.D. 1957, University of Chicago. Dean Sandalow made these remarks at the 1980 Law Review Banquet, which honored Professors Conard and Smith. - Ed. 
ence. It may also become an exercise in self-indulgence. Al has understood, perhaps better than most of us, that law professors, unlike those in purely academic disciplines, are not engaged in training students to become replicas of themselves. Nearly all law students are headed for careers markedly different from those of their teachers. Al's teaching and his contributions to the School's curricular planning have consistently been informed by an awareness of the importance of that difference.

There are, as I have already indicated, others who can speak more knowledgeably than I about the importance of Al's scholarly contributions, but a few comments may nonetheless be appropriate. Al's work is notable, among other reasons, because of the variety of perspectives from which he has viewed the issues that he has studied. A considerable portion of the work that he has published consists of relatively conventional legal scholarship - conventional, I should say, in its method of analysis, not in its quality. This work alone, I am told, would establish his place as one of the most important legal scholars of his generation and as a dominant figure in the corporate field. $\mathrm{He}$ is, however, also a distinguished comparativist whose work has gained international recognition. Al has, moreover, been one of the nation's most influential exponents and practitioners of empirical research. The classic study on Automobile Accident Costs and Payments which he co-authored with Morgan and others laid the foundation for the "no fault" movement. (If I may digress for a moment, I should say that I have always thought it somewhat incongruous that $\mathrm{Al}$ should have been one of the founders of the "no-fault" movement, since I have never known him to find "no fault" with his colleagues, and certainly not with deans.)

Allan Smith's career has taken a very different course. It is worth noting by way of introduction that the very first item in his personnel file is a confession of error. I do not wish to suggest that this was a portent of the future, but it is so rare an occurrence to find Allan in error, let alone admitting the error, that I think I should share this story with you. Prior to the war, Allan did graduate work at the Law School. Apparently, though our records are unclear on this point, he returned to Ann Arbor for a brief period after the war. In September 1946, he left Ann Arbor to assume a position as an assistant professor of law at Stanford. Barely two months later, on November 13, he wrote Dean Stason:

After two months in 'sunny California' I am ... of the opinion that I ... made an erroneous choice and should have stayed in Michigan. Accordingly, if I'm still eligible for a vacancy for the fall of 1947, you 
may consider this an acceptance and I will include with it an unlimited permission to say 'I told you so.'

Allan's repentance was the beginning of an association that has continued for thirty-four years and that has, from the point of view of the Law School and the University, been remarkably fruitful. Before commenting on that career, I should merely like to point out to Allan the lesson to be derived from this experience: listen to the dean; he knows best. This is, I appreciate, a maxim in which Allan deeply believed for a brief period, but he has not always remembered it. May I say, Allan, that if you wish to atone for these occasional lapses, you might undertake the Herculean task of persuading our friend Al Conard that the maxim is not always and invariably false.

Between 1947 and 1960 Allan served as a member of the faculty. From the very beginning, our alumni have told me, he was one of the School's most popular and effective teachers. His superb abilities as a teacher continue to the present day. Every member of this faculty is admired by some part of the student body. Very few escape criticism from some. Allan has the wondrous capacity to reach all segments of the student body, inspiring both their affection and their respect. His classes emphasize the need for both technical proficiency and an understanding of the broad themes of the law. No less important, ultimately perhaps more important, is the high standard Allan sets for his students, his insistence that they give the very best of which they are capable.

The years from 1947 to 1960 were also the time that Allan established a reputation as a scholar in the field of property law. It would be disingenuous for me to appraise his work, which I have not read, but it must have been of very high quality, for had it not the faculty would not have submitted Allan's name to the President as its choice for dean upon the retirement of Blythe Stason. On the other hand, the faculty must not have regarded the work so highly that it was unwilling to move Allan from the productive world of scholarship to the drudgery of deanship.

Allan's deanship marks, in my mind, the beginning of the modern history of the Law School. Michigan has, of course, been a great law school for many years, and in every great institution there is continuity with the past. But great institutions also change, and it was during the years that Allan led the School that there began a process of change that accounts for the School's current strength. It would unduly lengthen these remarks to describe those changes other than to say that the most important changes in a school are 
always associated with the appointment of new faculty. Allan's term as dean was marked by the appointment of a large number of exceedingly able faculty members, many of whom have in the years since become important members of this faculty and major figures in the law.

In 1965 Allan was elevated to the position of Vice President for Academic Affairs, the chief academic officer of the University. The appointment reflects the esteem he had won in his service as dean. Nevertheless, it should be recognized that Allan assumed the VicePresidency under very difficult circumstances. The Vice President is the University's chief budget officer - the individual mainly responsible for allocating funds to the schools and colleges. Throughout the University there was concern that Allan would show favoritism to the Law School. The members of the law faculty, on the other hand, feared that he would not - indeed, that he would bend over backwards to avoid showing favoritism. Allan handled this difficult situation so deftly that by 1974 , when he relinquished the office, both camps were persuaded that their fears had been justified.

If I may be serious for a moment, I think I can say with some assurance that my views would be shared throughout the University community that Allan guided the University through an exceedingly difficult period with the same skill and the same success as he had earlier led the Law School. During the years that he was its chief academic officer, the University gained markedly in strength and stature. Such progress is never the work of a single person, but Allan's judgment and skill, his understanding of and dedication to the central purposes of the University, were undoubtedly factors of major importance. The widespread admiration for Allan's contributions made it possible for the Regents to appoint him Interim President with full confidence that he would enjoy the support of the entire University.

We must be cautious in praising Professors Conard and Smith not to bury them. Each has nearly two full years of active service remaining before retirement, and many contributions to make following retirement. But judging only by the contributions that they have made so far, each has earned a major place in any history that may ultimately be written of the Law School and the University. Their labors have been of inestimable value to the School, and thus to the nation and the world. We are deeply grateful to them. 